\title{
Penerapan Model Discovery Learning dengan Media Model untuk Meningkatkan Pembelajaran Matematika tentang Bangun Ruang pada Siswa Kelas V SD Negeri 7 Kutosari Tahun Ajaran 2018/2019
}

\author{
Nur Rofiqoh ${ }^{1}$, Ngatman $^{2}$, Joharman ${ }^{3}$ \\ 1,2.2Universitas Sebelas Maret \\ rofiqohnur12@student.uns.ac.id
}

\section{Article History}

accepted 01/10/2019

approved 01/11/2019

published 01/12/2019

\begin{abstract}
This study aimed to improve mathematics learning about the improvement of grade $V$ students of SD Negeri Kutosari 7 by applying discovery learning models with media models. This research is collaborative classroom action research. The subjects of this study were teachers and grade $V$ students. Data collection techniques used observation, interviews, documentation, and tests. Data validity used source triangulation, technique triangulation, and content validity. Data analysis was conducted through data reduction, data presentation, and conclusion. The results showed that the application of the discovery learning model with media models could improve mathematics learning about shapes in grade $V$ students of SD Negeri 7 Kutosari in Academic Year 2018/2019.
\end{abstract}

Keywords: discovery learning, media models, shapes

\section{Abstrak:}

Tujuan penelitian ini yaitu: meningkatkan pembelajaran matematika tentang bangun ruang siswa kelas V SD Negeri 7 Kutosari dengan menerapkan model discovery learning. Penelitian ini merupakan penelitian tindakan kelas kolaboratif. Subjek penelitian ini adalah guru dan siswa kelas $\mathrm{V}$. Teknik pengumpulan data menggunakan: observasi, wawancara, dokumentasi, dan tes. Validitas data menggunakan triangulasi sumber, triangulasi teknik, dan validitas isi. Analisis data melalui reduksi data, penyajian data, dan penarikan kesimpulan. Hasil penelitian menunjukkan bahwa penerapan model discovery learning dengan media model dapat meningkatkan pembelajaran matematika tentang bangun ruang pada siswa kelas $\mathrm{V}$ SD Negeri 7 Kutosari tahun ajaran 2018/2019.

Kata kunci: discovery learning, media model, bangun ruang 


\section{PENDAHULUAN}

Pendidikan memiliki peran penting dalam kehidupan manusia. Melalui pendidikan, dapat terbentuk manusia yang memiliki adab, sikap, moral, pengetahuan serta karakter sesuai dengan kodrat manusia yang sesungguhnya. Pendidikan juga berperan dalam kemajuan suatu negara. Tanpa adanya pendidikan, suatu negara sulit untuk menjadi negara yang maju. Majunya suatu negara dapat dilihat dari sistem pendidikan dan kualitas pendidikannya, sehingga mutu pendidikan harus selalu ditingkatkan.

Upaya-upaya yang telah dilakukan pemerintah Indonesia untuk meningkatkan mutu pendidikan antara lain yaitu melakukan pembaruan kurikulum. Pembaruan kurikulum yang dilakukan yaitu dengan menggantikan KTSP (Kurikulum Tingkat Satuan Pendidikan) dengan kurikulum 2013.

Dalam pembelajaran abad 21 , seorang guru harus mempunyai beberapa karakteristik antara lain yaitu (1) pembelajaran berpusat pada peserta didik; (2) menciptakan susasana yang menarik, menyenangkan, dan bermakna; (3) peserta didik aktif dalam pembelajaran; (4) menciptakan pembelajaran dalam situasi nyata dan konteks sebenarnya yaitu melalui pendekatan kontekstual (Hosnan, 2014: 85). Oleh sebab itu, guru dituntut untuk menciptakan pembelajaran yang kondusif, sehingga harus memilih model dan media pembelajaran yang tepat. Pemilihan tersebut harus sesuai dengan mata pelajaran maupun karakteristik dari siswa, tidak terkecuali pada mata pelajaran matematika.

Wahyudi (2015: 68) menyatakan bahwa, Matematika adalah suatu bahan kajian yang memiliki objek abstrak dan dibangun dengan proses penalaran deduktif, yaitu kebenaran suatu konsep yang diperoleh sebagai akibat logis dari kebenaran sebelumnya yang sudah diterima, sehingga kebenaran antarkonsep dalam matematika bersifat sangat kuat dan jelas. Oleh karena itu, untuk membantu siswa memahami konsep matematika yang abstrak, guru diharuskan menggunakan model dan media pembelajaran yang sesuai dengan karakteristik siswa.

Berdasarkan hasil wawancara dan observasi yang dilakukan peneliti pada Jumat, 9 November 2018 di kelas V SD Negeri 7 Kutosari, proses pembelajaran yang berlangsung belum optimal. Saat pembelajaran matematika berlangsung, media yang digunakan guru cenderung bersifat abstrak. Meskipun sudah menggunakan media, namun guru kurang melibatkan siswa dalam pembelajaran, dan pembelajaran hanya bersifat satu arah. Guru menjadi pemberi informasi, sehingga pembelajaran hanya berfokus pada guru (teacher center). Selain itu, akibatnya ada beberapa siswa yang terlihat bosan, mengantuk dan berbicara dengan temannya. Hal tersebut berpengaruh terhadap hasil belajara siswa, antara lain hasil Penilaian Tengah Semester (PTS) mata pelajaran matematika. Pada Kompetensi Dasar (KD) 3.1 dan 4.1, dari 31 siswa, hanya 12 siswa yang nilainya mencapai Kriteria Ketuntasan Minimal (KKM) yaitu 70 atau dengan ketuntasan 38,70\%. Pada KD 3.2 dan 4.2, dari 31 siswa, hanya 8 siswa yang nilainya mencapai KKM dengan ketuntasan 25,80\%.

Berdasarkan permasalahan tersebut, peneliti menawarkan solusi pembelajaran dengan menerapkan model pembelajaran yang mengaktifkan siswa, berpusat pada siswa, serta membantu siswa memahami kaidah-kaidah matematika yang abstrak melalui penerapan model discovery learning dengan media model.

Rabbani dan Herman (2017: 121), menyatakan bahwa 'model discovery learning adalah salah satu model pembelajaran yang melibatkan partisipasi aktif siswa dalam mengeksplorasi dan menemukan pengetahuan mereka sendiri serta menggunakannya dalam pemecahan masalah'. Lebih lanjut Prince (Ramdhani, Usodo dan Subanti, 2017:2) menyatakan bahwa discovery learning merupakan salah satu model untuk mengembangkan metode pembelajaran yang mengaktifkan siswa dengan mencari dan menyelidiki sendiri, sehingga hasil yang didapatkan bertahan lama dalam ingatan, dan tidak mudah dilupakan oleh siswa. 
Menurut Padmono (2011: 40), model adalah media yang mewakili benda aslinya, yang berukuran lebih besar, lebih kecil, ataupun sama dengan benda aslinya. Selain itu, model merupakan benda tiruan dalam wujud tiga dimensi yang dapat diamati dari segala arah sebagai pengganti dari benda sesungguhnya (Asyhar, 2012: 56). Oleh karena itu, media model merupakan salah satu media yang cocok digunakan untuk untuk membantu siswa dalam memahami konsep matematika yang abstak dalam pembelajaran.

Dalam penelitian ini, model discovery learning dengan media model diterapkan pada materi pembelajaran tentang bangun ruang. Menurut Wahyudi (2015: 368), bangun ruang adalah bangun berdimensi tiga yang mengandung tiga unsur, yaitu panjang, lebar, dan tinggi. Lebih lanjut Suhardjana (2008: 5), menyatakan bahwa bangun ruang merupakan bagian ruang yang dibatasi himpunan-himpunan titik yang terdapat pada seluruh permukaan bangun tersebut.

Penerapan model discovery learning dengan media model melalui enam langkah pokok yaitu: stimulation dengan media model, problem statement dengan media model, data collection dengan media model, data processing dengan media model, verification dengan media model, generalization dengan media model. Langkah-langkah ini sesuai dengan pendapat Hosnan (2014: 289-291) yaitu: stimulation, problem statement, data collection, data processing, verification, generalization dan didukung oleh pendapat Ahmadi \& Prasetya (Illahi, 2012: 87-88) yang menyatakan bahwa ada beberapa prosedur dalam discovery learning meliputi: simulation, problem statement, data collection, data processing, verification, generalization. Untuk mendukung setiap langkah pembelajaran, maka peneliti menggunakan bantuan media model.

Rumusan masalah dalam penelitian ini yaitu (1) bagaimana penerapan model discovery learning dengan media model untuk meningkatkan pembelajaran matematika tentang bangun ruang pada siswa kelas V SD Negeri 7 Kutosari tahun ajaran 2018/2019? (2) apakah penerapan model discovery learning dengan media model dapat meningkatkan pembelajaran matematika tentang bangun ruang pada siswa kelas V SD Negeri 7 Kutosari tahun ajaran 2018/2019? (3) bagaimana kendala dan solusi penerapan model discovery learning dengan media model untuk meningkatkan pembelajaran matematika tentang bangun ruang pada siswa kelas V SD Negeri 7 Kutosari tahun ajaran 2018/2019?

Penelitian ini bertujuan untuk (1) mendeskripsikan penerapan model discovery learning dengan media model untuk meningkatkan pembelajaran matematika tentang bangun ruang pada siswa kelas V SD Negeri 7 Kutosari tahun ajaran 2018/2019; (2) meningkatkan pembelajaran matematika tentang bangun ruang, melalui penerapan model discovery learning dengan media model pada siswa kelas V SD Negeri 7 Kutosari tahun ajaran 2018/2019; (3) mendeskripsikan kendala dan solusi penerapan model discovery learning dengan media model untuk meningkatkan pembelajaran matematika tentang bangun ruang pada siswa kelas V SD Negeri 7 Kutosari tahun ajaran 2018/2019.

\section{METODE}

Penelitian ini adalah penelitian tindakan kelas (PTK) kolaboratif antara peneliti sebagai perancang tindakan dan guru kelas sebagai pelaksana tindakan yang dirancang bersama peneliti. Penelitian ini dilakukan di SD Negeri 7 Kutosari pada semester II. Subjek dari penelitian ini adalah guru dan seluruh siswa kelas V SD Negeri 7 Kutosari tahun ajaran 2018/2019.

Data yang digunakan dalam penelitian ini yaitu data kuantitatif berupa nilai hasil belajar siswa pada pembelajaran matematika dan data kualitatif berupa informasi pelaksanaan pembelajaran matematika dengan menerapkan model discovery learning dengan media model tentang bangun ruang. 
Sumber data pada penelitian ini yaitu siswa dan guru, dengan teknik pengumpulan data melalui nontes dan tes. Teknik nontes yaitu dengan observasi, wawancara, dan dokumentasi, sedangkan teknik tesnya menggunkan tes tertulis. Uji validitas data menggunakan triangulasi sumber, triangulasi teknik, dan validitas isi. Data tersebut kemudian dianalisis dengan tiga tahapan yaitu: (1) reduksi, (2) penyajian data, dan (3) penarikan kesimpulan.

Indikator kinerja penelitian dari penelitian ini ditargetkan mencapai $85 \%$. Aspek yang diukur berupa proses pembelajaran dari segi guru dan siswa serta hasil pelaksanaan pembelajaran melalui penerapan model discovery learning dengan media model. KKM hasil belajar yang ditargetkan pada penelitian ini yaitu 70 .

Penelitian dilaksanakan selama 2 siklus, yang terdiri dari 3 pertemuan pada setiap siklusnya. Tahapan dari penelitian sesuai dengan pendapat Arikunto (2013: 137) yaitu (1) perencanaan, (2) pelaksanaan, (3) observasi, dan (4) refleksi.

\section{HASIL DAN PEMBAHASAN}

Penerapan model discovery learning dengan media model dilaksanakan sesuai dengan langkah-langkah pokok yaitu: stimulation dengan media model, problem statement dengan media model, data collection dengan media model, data processing dengan media model, verification dengan media model, generalization dengan media model. Data hasil observasi dari 3 observer terkait penerapan discovery learning dengan media model sebagai berikut:

Tabel 1. Hasil Observasi terhadap Guru dan Siswa

\begin{tabular}{|c|c|c|c|}
\hline & & Guru & Siswa \\
\hline \multirow{2}{*}{$\frac{\mathscr{D}}{\frac{\Sigma}{\bar{D}}}$} & I & $76,67 \%$ & 72,50 \\
\hline & II & $89,44 \%$ & $88,33 \%$ \\
\hline
\end{tabular}

Berdasarkan Tabel 1, persentase rata-rata hasil observasi guru pada siklus I yaitu $76,67 \%$ dan meningkat pada siklus II menjadi $89,44 \%$. Hasil observasi siswa pada siklus I dengan persentase $72,50 \%$, mengalami peningkatan pada siklus II menjadi $88,33 \%$. Jadi, secara keseluruhan penerapan model discovery learning dengan media model dinyatakan berhasil dan mencapai target indikator kinerja penelitian.

Peningkatan pembelajaran matematika tentang bangun ruang pada siswa kelas $\checkmark$ SD Negeri 7 Kutosari meliputi peningkatan proses dan hasil. Peningkatan proses telah dijelaskan sebelumnya pada langkah-langkah penerapan model discovery learning dengan media model dari segi guru maupun siswa. Berikut pemaparan mengenai peningkatan pembelajaran pada siklus I dan II jika ditinjau dari segi hasil.

\begin{tabular}{llll} 
Tabel 2. Peningkatan Hasil Belajar Antarsiklus \\
\cline { 2 - 4 } Siklus & $\begin{array}{l}\text { Rata- } \\
\text { rata } \\
\text { Nilai }\end{array}$ & $\begin{array}{l}\text { Ketuntasan } \\
(\%)\end{array}$ & $\begin{array}{l}\text { Tuntas } \\
\text { Buntas } \\
(\%)\end{array}$ \\
\hline I & 69,94 & 75,56 & 28,33 \\
\hline II & 77,39 & 87,78 & 12,22 \\
\hline
\end{tabular}

Berdasarkan tabel di atas, dapat disimpulkan bahwa ketuntasan nilai siswa mengalami peningkatan dan telah mencapai taget indikator kinerja penelitian. Pada siklus I persentase ketuntasan siswa yaitu $75,56 \%$. Siklus II persentase ketuntasan 
yaitu $87,78 \%$. Kendala yang muncul dalam pembelajaran yaitu: (a) siswa belum berani untuk bertanya dengan suara yang tinggi hal-hal yang belum dipahami; (b) guru kurang mengondisikan siswa untuk mendengarkan kelompok presentator; (c); membutuhkan banyak waktu. Adapun solusi dari kendala tersebut adalah: (a) guru memberi motivasi kepada siswa untuk berani bersuara tinggi; (b) guru melakukan pengondisian kelas secara menyeluruh; (c) mengingatkan guru untuk memperhatikan waktu pembelajaran yang telah direncanakan.

\section{SIMPULAN}

Berdasarkan hasil penelitian dan pembahasan di atas, dapat disimpulkan bahwa penerapan model discovery learning dengan media model dapat meningkatkan pembelajaran matematika tentang bangun ruang baik dari segi proses maupun hasil pembelajaran.

\section{DAFTAR PUSTAKA}

Asyhar, R. (2012). Kreatif Mengembangkan Media Pembelajaran. Jakarta: Referensi Jakarta.

Hosnan. (2014). Pendekatan Saintifik dan Kontekstual dalam Pembelajaran Abad 21. Bogor: Ghalia Indonesia.

Illahi, M. (2012). Pembelajaran Discovery Strategy \& Mental Vocational Skill. Yogyakarta: DIVA Press.

Padmono, Y. (2011). Media Pembelajaran. Kebumen: UNS.

Rabbani, S. dan Herman, T. (2017). Increasing Formulate and Test Conjecture Math Competence and Self Confidence in Using the Discovery Learning Teaching Math. Journal of Elementary Education, 1 (1), 119-128. Diperoleh pada tanggal $14 \quad$ November 2018 dari http://www.ejournal.stkipsiliwangi.ac.id/index.php/primaryedu/article/view/488

Ramdhani, M.R., Usodo, B. dan Subanti, S. (2017). Discovery Learning with Scientific Approach on Geometry. Journal of Physics: Conference Series. 895 (2017) 012033. Diperoleh pada tanggal 14 November 2018 dari http://iopscience.iop.org/article/10.1088/1742-6596/895/1/012033/pdf.

Suhardjana, A. (2008). Pengenalan Bangun Ruang dan Sifat-sifatnya di SD. Yogyakarta: Pusat Pengembangan dan Pemberdayaan Pendidik dan Tenaga Kependidikan Matematika.

Wahyudi. (2015). Pembelajaran Matematika di Sekolah Dasar. Surakarta: FKIP UNS. 